\title{
DEVELOPING INTEGRATION TECHNIQUES MODULE TO IMPROVE MATHEMATICAL CREATIVE THINKING ABILITY IN INTEGRAL CALCULUS
}

\author{
Titi Solfitri' ${ }^{1}$, Hesty Marwani Siregar ${ }^{2}$ \\ 1,2 Program Studi Pendidikan Matematika Universitas Riau, Pekanbaru, Indonesia \\ ${ }^{1}$ titi.solfitri@lecturer.unri.ac.id, ${ }^{2}$ hesty.marwani@lecturer.unri.ac.id
}

\begin{abstract}
This study aimed to 1) to find out the effectiveness of the integration technique module in integral calculus learning, and 2) to find out the increase in the mathematical creative thinking ability after implementing the integration technique module in integral calculus learning. The development of module was conducted by using ADDIE model with five stages: Analysis, Design, Development, Implementation, and Evaluation. The subjects in this study were 16 students in the 3rd semester of Mathematics Education Study Program, the Faculty of Teacher Training and Education, Universitas Riau. The research instruments were an expert validation questionnaire, a student response questionnaire, and a mathematical creative thinking ability test. The data obtained were analyzed by using quantitative and qualitative descriptive analysis methods. Based on the results of the validity test, the integration technique module was declared valid and suitable for students to use in the integral calculus course. Judging from the results of the module practicality test, the average percentage of practicality values was 77.8125 and was in the practical category. Referring to the results of the module effectiveness test, the n-gain average of students' mathematical creative thinking abilities was 0.64 and in the medium category. Because the integrated engineering module met the criteria of validity, practicality, and effectiveness, it could be stated that the developed integration technique module improved students' mathematical creative thinking skills in the integral calculus course.
\end{abstract}

Keywords: integral calculus module, integration techniques, mathematical creative thinking ability

\section{PENGEMBANGAN MODUL TEKNIK INTEGRASI UNTUK MENINGKATKAN KEMAMPUAN BERPIKIR KREATIF MATEMATIS PADA MATAKULIAH KALKULUS INTEGRAL}

\begin{abstract}
ABSTRAK
Tujuan pada penelitian ini yaitu 1) Untuk mengetahui bagaimana keefektifan modul teknik integrasi pada pembelajaran kalkulus integral, dan 2) Untuk mengetahui apakah terdapat peningkatan kemampuan berpikir kreatif matematis dengan penggunaan modul teknik integrasi pada pembelajaran kalkulus integral. Pengembangan modul dilakukan dengan menggunakan model ADDIE yang memiliki lima tahapan yaitu Analysis, Design, Development, Implementation, dan Evaluation. Subjek dalam penelitian ini yaitu mahasiswa semester 3 pada Program Studi Pendidikan Matematika Fakultas Keguruan dan Ilmu Pendidikan Universitas Riau sebanyak 16 orang. Instrumen pengumpulan data penelitian adalah angket validasi ahli, angket respon mahasiswa, dan tes kemampuan berpikir kreatif matematis. Data yang diperoleh dianalisis dengan menggunakan metode analisis deskriptif kuantitatif dan kualitatif. Berdasarkan hasil uji validitas, modul teknik integrasi dinyatakan valid dan layak digunakan mahasiswa pada matakuliah kalkulus integral. Dilihat dari hasil uji kepraktisan modul, rata-rata persentase nilai kepraktisan sebesar 77.8125 dan berada pada kategori praktis. Merujuk pada hasil uji keefektifan modul, rata-rata n-gain kemampuan berpikir kreatif matematis mahasiswa sebesar 0.64 dan berada pada kategori sedang. Karena modul teknik integrasi telah memenuhi kriteria validitas, kepraktisan, dan keefektifan, maka dapat dikatakan bahwa modul teknik integrasi yang dikembangkan dapat meningkatkan kemampuan berpikir kreatif matematis mahasiswa pada matakuliah kalkulus integral.
\end{abstract}

Kata Kunci: modul kalkulus integral, teknik integrasi, kemampuan berpikir kreatif matematis

\begin{tabular}{|c|c|c|}
\hline Submitted & Accepted & Published \\
\hline 23 November 2020 & 24 Februari 2021 & 26 Maret 2021 \\
\hline
\end{tabular}

\begin{tabular}{|l|c|c|c|}
\hline Citation & $:$ & $\begin{array}{r}\text { Solfitri, T., \& Siregar, H.M. (2021). Developing Integration Techniques Module to Improve Mathematical Creative } \\
\text { Thinking Ability in Integral Calculus. Jurnal PAJAR (Pendidikan dan Pengajaran), 5(2), 296-305. DOI : } \\
\text { http://dx.doi.org/10.33578/pjr.v5i2.8221. }\end{array}$ \\
\hline
\end{tabular}

\section{PENDAHULUAN}

Pergeseran cara hidup dan proses kerja secara mendasar akibat kemajuan teknologi yang mengintegrasikan teknologi digital ke dalam kehidupan manusia, sehingga berpengaruh bagi seluruh disiplin ilmu disebut revolusi industri (Hamdan, 2018). Revolusi industri dimulai dari 
revolusi industry 1.0 hingga yang kita kenal saat ini revolusi industri 4.0. Revolusi industri 4.0 mempengaruhi pendidikan dalam cara belajar, pola pikir, cara bertindak, serta kemampuan yang diharapkan dapat diperoleh mahasiswa setelah mempelajari suatu materi. Mahasiswa tidak hanya dituntut untuk memahami suatu materi tetapi juga dapat mengembangkan aspek afektif mereka, seperti kemampuan bernalar, berpikir kritis, berpikir kreatif, literasi, dan lain-lain.

Salah satu materi yang penting dipelajari mahasiswa adalah materi matematika. Hal ini disebabkan karena kehidupan sehari-hari manusia tidak luput dari proses matematika. Dari mulai bangun tidur hingga tidur kembali, selalu ada unsur matematika yang terdapat dalam aktivitas manusia. Selain itu, melalui pembelajaran matematika, tidak hanya pemahaman matematis saja yang dapat tercapai, tetapi kemampuan berpikir tingkat tinggi juga dapat diraih, contohnya kemampuan berpikir kreatif. Hal ini sesuai dengan pernyataan yang dikemukakan Handoko (2017), bahwa matematika dapat digunakan dalam pengembangan kemampuan berpikir kreatif, logis, sistematis, kerjasama, dan disiplin yang diperlukan untuk bersaing di dunia modern saat ini. Pada saat mempelajari matematika, peserta didik akan mengenal korelasi dan pola generalisasi pengalaman, sehingga berpengaruh pada peningkatan kreativitas dan kesadaran mahasiswa dalam mengikuti perkembangan sosial budaya masyarakat (Arhasy \& Mulyani, 2017).

Pengembangan kemampuan berpikir mahasiswa perlu menjadi perhatian pendidik. Belajar matematika tidak lepas dari aktivitas dan proses belajar serta berpikir, karena karakteristik matematika merupakan suatu ilmu dan aktivitas manusia, yaitu bahwa matematika merupakan pola pikir, cara mengorganisasikan pembuktian yang logis, menggunakan istilah yang didefinisikan dengan cermat, jelas, dan akurat (Sabandar dalam Arhasy dan Mulyani, 2017). Pola pikir pada aktivitas matematika dikelompokkan ke dalam berpikir tingkat rendah dan berpikir tingkat tinggi. Salah satu kemampuan berpikir tingkat tinggi pada matematika adalah kemampuan berpikir kreatif matematis. Pengembangan proses berpikir tingkat tinggi, khususnya berpikir kreatif matematis, sejalan dengan tujuan pembelajaran matematika. Tujuan pembelajaran matematika salah satunya untuk mengembangkan aktivitas kreatif yang menyangkut imajinasi, intuisi dan penemuan, melalui pengembangan pemikiran orisinal, divergen, rasa ingin tahu, membuat prediksi dan dugaan, serta mencoba-coba (Siswono, 2006).

Pengembangan ranah kognitif pada pendidikan formal perlu mendapat perhatian. Pada pembelajaran baik di sekolah maupun di kampus, jarang sekali ada kegiatan yang menuntut pemikiran divergen atau pemikiran kreatif sehingga siswa tidak mendapat stimulus untuk berpikir, bersikap, dan berperilaku kreatif. Hal ini dirasakan peneliti selama mengajar mahasiswa tingkat pertama pada mata kuliah kalkulus integral. Mahasiswa tidak berbiasa menghadapi soal-soal non rutin khususnya soal berpikir kreatif. Mahasiswa tidak terbiasa untuk berpikir orisinil dan fleksibel. Dalam menjawab soal integral, mahasiswa terbiasa fokus pada satu cara. Selain itu, mahasiswa juga kurang bisa dalam menentukan cara termudah untuk menyelesaikan suatu soal. Pengalaman ini juga didukung oleh hasil penelitian sebelumnya. Amidi (2018) menyatakan bahwa metode pembelajaran dengan presentasi dan praktik, menggunakan masalah tertutup dan jawaban yang telah ditentukan sebelumnya, kurang memadai dalam mempersiapkan mahasiswa mengembangkan kemampuan berpikir kreatif.

Berdasarkan pengalaman peneliti selama ini dan berdasarkan hasil penelitian peneliti lain sebelumnya, dalam proses pembelajaran diperlukan cara yang mendorong mahasiswa untuk memahami masalah, mengembangkan kemampuan berpikir kreatif mahasiswa dalam menyelesaikan masalah yang diberikan, melibatkan mahasiswa secara aktif dalam menemukan sendiri penyelesaian masalah, serta mendorong pembelajaran yang berpusat pada mahasiswa dan dosen hanya sebagai fasilitator.

Amidi (2018) menyatakan bahwa metode pembelajaran dengan presentasi dan praktik, menggunakan masalah tertutup dan jawaban yang telah ditentukan sebelumnya, kurang memadai 
dalam mempersiapkan mahasiswa mengembangkan kemampuan berpikir kreatif. Berdasarkan penelitian yang dilakukan Faelasofi (2017), kemampuan kreatif matematis mahasiswa pada materi peluang masih tergolong rendah karena skor yang dicapai sebesar 59,26. Penelitian yang dilakukan Suripah dan Sthephani (2017) memperoleh hasil bahwa penguasaan berpikir matematis mahasiswa berkemampuan tinggi, sedang dan rendah belum merata. Siswa berkemampuan sedang dan rendah belum menguasai keseluruhan aspek berpikir kreatif matematis. Dari hasil penelitian tersebut, dan untuk menjawab tantangan revolusi industri, perlu adanya tindakan yang dilakukan untuk mengembangkan kemampuan berpikir kreatif. Salah satunya dengan melatih mahasiswa untuk berusaha mencari informasi terkait materi yang dipelajarinya secara mandiri.

Perkembangan ilmu pengetahuan dan teknologi yang semakin pesat mengakibatkan informasi dapat diakses dengan mudah menggunakan media internet. Informasi yang tersebar dapat membantu menunjang pemahaman mahasiswa dalam suatu materi, tetapi dapat pula menyesatkan jika mahasiswa tidak mempunyai pedoman dan pondasi yang kokoh dalam menerima arus informasi. Oleh karena itu, diperlukan bahan ajar sebagai pendamping mahasiswa dalam memahami suatu materi serta sebagai pedoman dan arah bagi mahasiswa untuk menerima informasi yang benar.

Bahan ajar adalah seperangkat materi pelajaran yang yang bertujuan untuk mencapai standar kompetensi dan kompetensi dasar yang telah ditentukan serta mengacu pada kurikulum yang berlaku (Lestari, 2013). Berdasarkan penelitian Novalia dan Noer (2019), kemampuan berpikir kreatif matematis mahasiswa meningkat melalui bahan ajar berupa modul pembelajaran matematika dengan strategi PQ4R. Sejalan dengan penelitian yang dilakukan oleh Novalia dan Noer, penelitian yang dilakukan oleh Citroresmi, dkk (2016) memperoleh hasil bahwa bahan ajar matematika berbasis masalah layak digunakan dalam proses pembelajaran matematika dan dapat meningkatkan kemampuan berpikir kreatif matematis siswa. Berpijak dari penelitian ini, peneliti tertarik untuk mengembangkan suatu bahan ajar yang dapat meningkatkan kemampuan berpikir kreatif mahasiswa pada matakuliah Kalkulus Integral.

Rumusan masalah pada penelitian ini yaitu 1) Bagaimana keefektifan modul teknik integrasi pada pembelajaran kalkulus integral, dan 2) Apakah terdapat peningkatan kemampuan berpikir kreatif dengan penggunaan modul teknik integrasi pada pembelajaran kalkulus integral. Sedangkan tujuan pada penelitian ini yaitu 1) Untuk mengetahui bagaimana keefektifan modul teknik integrasi pada pembelajaran kalkulus integral, dan 2) Untuk mengetahui apakah terdapat peningkatan kemampuan berpikir kreatif matematis dengan penggunaan modul teknik integrasi pada pembelajaran kalkulus integral.

\section{KAJIAN TEORETIS}

Telah banyak penelitian yang dilakukan peneliti-peneliti lain terkait kemampuan berpikir kreatif matematis. Salah satu yang menjadi perhatian pada penelitian kemampuan berpikir kreatif matematis yaitu mengenai penyebab rendahnya pencapaian berpikir kreatif. Palah (2017) menyatakan bahwa belum adanya bahan ajar yang mendukung tercapainya kemampuan berpikir kreatif matematis yang optimal. Bahan ajar yang dipilih untuk digunakan dapat disesuaikan dengan kebutuhan mahasiswa, dalam hal ini kebutuhan untuk meningkatkan kemampuan berpikir kreatif matematis. Salah satu bahan ajar yang dapat memfasilitasi pengembangan kemampuan bepikir kreatif matematis adalah modul yang dirancang dengan tepat agar mahasiswa mampu belajar dengan efektif (Swestyani, Masyuri, \& Prayitno, 2014).

Penelitian yang dilakukan oleh Novalia \& Noer (2019) berjudul Pengembangan Modul Pembelajaran Matematika dengan Strategi PQ4R untuk Meningkatkan Kemapuan Berpikir Kreatif dan Kemandirian Belajar Siswa SMA. Data penelitian diperoleh melalui instrumen kemampuan berpikir kreatif dan skala kemandirian belajar. Analisis data menggunakan uji proporsi dengan program SPSS. Hasil uji proporsi tentang efektivitas terhadap penggunaan modul menunjukkan siswa telah memenuhi 
kriteria ketuntasan minimal dalam kemampuan berpikir kreatif dan kemandirian belajar. Berdasarkan hasil analisis dalam penelitian ini, terdapat peningkatan kemampuan berpikir kreatif dan kemandirian belajar siswa dengan menggunakan modul pembelajaran matematika dengan strategi PQ4R.

Penelitian yang dilakukan oleh Ramdani, Rohaeni, \& Sumardi (2018) berjudul Pengembangan Instrumen dan Bahan Ajar Kalkulus Integral Melalui Strategi Scientific Debate. Bahan ajar yang dikembangkan memuat sajian konsep, contoh soal rutin dan non-rutin, latihan soal rutin dan non-rutin, serta latihan soal aplikasi. Langkah-langkah yang dilakukan dalam mengembangkan bahan ajar dan instrument penelitian yang memiliki validitas, reliabilitas, tingkat kesukaran, dan daya pembeda yang memadai meliputi: 1) menganalisis secara teoretis instrument, rubrik, dan bahan ajar; 2) menganalisis secara teoretis tentang komunikasi, penalaran, dan koneksi matematis; 3) menganalisis secara empiris identifikasi permasalahan lapangan berkenaan dengan bahan ajar, pembelajaran, dan instrument dalam mengevaluasi; 4) mengembangkan prototype instrumen, rubrik, dan bahan ajar; 5) analisis teoretik instrumen, rubrik, dan bahan ajar; 6) model konseptual yang telah disusun kemudian divalidasi oleh pakar sesuai dengan keahliannya agar model konseptual tersebut mempunyai dasar teori yang ajeg dan sesuai dengan kaidah ilmiah; 7) penyempurnaan model instrumen; 8) ujicoba terbatas instrumen dan rubrik; 9) penyempurnaan instrumen dari rubrik. Hasil ujicoba instrumen memperoleh nilai signifikansi 0.42 , yang berarti bahwa bobot harus mempertimbangkan keabsahan item konten secara seragam. Nilai signifikansi 0.82 berarti bahwa validitas pertanyaan yang diuji jelas dari segi bahasa dan gambar. Nilai reliabilitas signifikansi 0.87 termasuk dalam kategori tinggi. Analisis menunjukkan tentang tingkat kesulitan kategori sulit terdapat pada soal nomor 7, sedangkan kategori sedang pada soal nomor $1,2,4$, dan 6 , serta kategori mudah pada soal nomor 3 dan 5. Analisis daya pembeda menunjukkan bahwa daya pembeda soal nomor 1 , 2, dan 3 cukup baik, soal nomor 4, 6, dan 7 termasuk dalam kategori baik, sedangkan soal nomor 5 termasuk kategori sangat baik.

Berdasarkan hasil penelitian yang sudah ada, maka kemampuan berpikir kreatif matematis dapat dikembangkan melalui pemberian bahan ajar berupa modul. Modul yang diberikan ini merupakan modul yang dirancang dan memuat langkah-langkah, kegiatan, maupun soal-soal non rutin yang dapat meningkatkan kemampuan berpikir kreatif matematis mahasiswa.

\section{METODE PENELITIAN}

Penelitian yang dilakukan merupakan jenis penelitian pengembangan. Sugiyono (2012) menyatakan bahwa penelitian pengembangan merupakan penelitian yang dilakukan untuk menghasilkan suatu produk kemudian menguji efektivitas produk tersebut. Produk yang dikembangkan pada penelitian ini yaitu modul kalkulus integral pada materi teknik integrasi. Pengembangan modul dilakukan dengan menggunakan model ADDIE yang memiliki lima tahapan yaitu Analysis, Design, Development, Implementation, dan Evaluation (Pribadi, 2009). Tahap Analysis merupakan tahap sebelum perencanaan yang meliputi analisis kurikulum, analisis mahasiswa, analisis materi pembelajaran, dan identifikasi kesenjangan.

Tahap ini penulis memutuskan modul yang sesuai kebutuhan mahasiswa adalah modul yang dapat mengoptimalkan kemampuan berpikir kreatif matematis. Pada tahap Design, dilakukan proses perancangan modul dimulai dari menentukan judul modul yaitu "Bahan Ajar Teknik Integrasi", materi pembelajaran yang dipilih yaitu teknik integrasi, dan format modul. Selanjutnya di tahap Development, rancangan modul diwujudkan ke dalam suatu modul yang sesuai dengan format yang telah ditetapkan sebelumnya. Modul yang telah dibuat kemudian dinilai oleh 2 orang validator ahli. Penilaian, saran, dan perbaikan dari kedua validator dipergunakan untuk memperbaiki modul pembelajaran. Tahap Implementation yaitu memberikan pretes kemampuan berpikir kreatif matematis, melakukan uji coba terbatas penggunaan modul kepada mahasiswa, dan memberikan postes kemampuan berpikir kreatif 
matematis. Tahap Evaluation adalah proses untuk menganalisis hasil ujicoba yang dilakukan pada tahap Implementation. Dari hasil analisis ini diperoleh ukuran kepraktisan dan keefektifan modul.

Penelitian ini dilaksanakan di Program Studi Pendidikan Matematika Fakultas Keguruan dan Ilmu Pendidikan Universitas Riau. Subjek dalam penelitian ini yaitu mahasiswa semester 3 Program Studi Pendidikan Matematika Fakultas Keguruan dan Ilmu Pendidikan Universitas Riau sebanyak 16 orang.

Instrumen penelitian terdiri dari angket dan tes. Angket yang digunakan terdiri dari angket validasi ahli untuk mengetahui tingkat validitas modul teknik integrasi yang digunakan dan angket respon siswa untuk mengukur derajat kepraktisan modul yang dikembangkan. Instrumen tes pada penelitian ini merupakan tes kemampuan berpikir kreatif matematis yang diujikan untuk memperoleh skor pretest dan posttest. Pengumpulan data dilakukan dengan uji coba produk menggunakan desain one-shot case study, yang merupakan desain yang menerapkan satu kali pengumpulan data. Data yang diperoleh merupakan data skor angket validitas instrumen penelitian oleh ahli, skor angket respon siswa, dan skor pretest dan posttest kemampuan berpikir kreatif matematis.

Data yang diperoleh dianalisis dengan menggunakan metode analisis deskriptif kuantitatif dan kualitatif. Analisis data hasil validasi dilakukan dengan menentukan rata-rata skor aspek-aspek modul untuk meningkatkan kemampuan berpikir kreatif matematis. Penentuan validitas modul disajikan pada Tabel berikut merujuk pada kategori validitas modul yang dikemukakan oleh Subekti \& Akhsani (2020).

Tabel 1. Kriteria Validitas Modul

\begin{tabular}{cl}
\hline \multicolumn{1}{c}{ Skor } & \multicolumn{1}{c}{ Kategori } \\
\hline $1,00 \leq \bar{x} \leq 1,75$ & Kurang Valid \\
$1,75<\bar{x} \leq 2,50$ & Cukup Valid \\
$2,50<\bar{x} \leq 3,25$ & Valid \\
$3,25<\bar{x} \leq 4,00$ & Sangat Valid \\
\hline
\end{tabular}

Untuk mengetahui tingkat kepraktisan modul, skor yang diperoleh dari angket respon siswa diubah ke dalam bentuk persentase dengan merujuk kepada Akbar (2013). Rumus yang digunakan yaitu sebagai berikut.

$p=\frac{\text { Total skor jawaban mahasiswa }}{\text { total skor maksimal harapan }} \times 100 \%$
Hasil persentase tersebut kemudian diklasifikasikan ke dalam kriteria kepraktisan modul, yang dapat dilihat pada tabel berikut (Akbar, 2013).

Tabel 2. Kriteria Kepraktisan Modul

\begin{tabular}{lll}
\hline No & \multicolumn{1}{c}{ Persentase Kepraktisan $(\%)$} & \multicolumn{1}{c}{ Level Kepraktisan } \\
\hline 1 & $80<p \leq 100$ & Sangat praktis \\
2 & $60<p \leq 80$ & Praktis \\
3 & $40<p \leq 60$ & Kurang praktis \\
4 & $20<p \leq 40$ & Tidak praktis \\
5 & $0 \leq p \leq 20$ & Sangat tidak praktis \\
\hline
\end{tabular}

Tingkat keefektifan modul dilihat dari peningkatan kemampuan berpikir kreatif matematis. Peningkatan ini dilihat dengan terlebih dahulu menentukan skor pretes dan postes kemampuan berpikir kreatif matematis. Selanjutnya penulis menentukan besaran n-gain kemampuan berpikir kreatif matematis mahasiswa menggunakan rumus berikut. 

selanjutnya ditentukan tingkatan n-gain mahasiswa. Tingkat Tinggi rendahnya n-gain dikelompokkan berdasarkan kriteria berikut.

Tabel 3. Kriteria N-Gain Kemampuan Berpikir Kreatif Matematis Mahasiswa

\begin{tabular}{cc}
\hline Besarnya n-gain $(\mathrm{g})$ & Interpretasi \\
\hline$g \geq 0,7$ & Tinggi \\
$0,3 \leq g<0,7$ & Sedang \\
$g<0,3$ & Rendah \\
\hline
\end{tabular}

HASIL DAN PEMBAHASAN

Modul teknik integrasi dapat dilihat kelayakannya dari unsur validitas, kepraktisan, dan efektivitas. Hasil validasi modul oleh 2 orang ahli dapat dilihat pada tabel berikut.

Tabel 4. Hasil Validasi Modul Teknik Integrasi

\begin{tabular}{|c|c|c|c|c|c|}
\hline \multirow{2}{*}{ No } & \multirow{2}{*}{ Butir Penilaian } & \multicolumn{2}{|c|}{ Nilai Validator } & \multirow{2}{*}{$\begin{array}{l}\text { Rata- } \\
\text { Rata }\end{array}$} & \multirow{2}{*}{ Keterangan } \\
\hline & & V1 & V2 & & \\
\hline \multicolumn{6}{|c|}{ Materi } \\
\hline 1. & $\begin{array}{l}\text { Materi sesuai dengan kebenaran dalam bidang } \\
\text { ilmu matematika }\end{array}$ & 3 & 4 & 3.5 & Sangat Valid \\
\hline 2. & Materi disajikan secara sistematis & 3 & 4 & 3.5 & Sangat Valid \\
\hline 3. & Penyajian konsep tidak bermakna ganda & 3 & 3 & 3 & Valid \\
\hline 4. & Uraian materi sesuai kemampuan siswa & 4 & 4 & 4 & Sangat Valid \\
\hline 5. & $\begin{array}{l}\text { Terdapat latihan untuk menunjang kejelasan } \\
\text { materi }\end{array}$ & 3 & 3 & 3 & Valid \\
\hline Rata & ata Aspek ke-I & 3.4 & & & Sangat Valid \\
\hline \multicolumn{6}{|c|}{ Pembelajaran } \\
\hline 6. & $\begin{array}{l}\text { Bahan ajar menempatkan mahasiswa sebagai } \\
\text { subjek }\end{array}$ & 3 & 3 & 3 & Valid \\
\hline 7. & Bahan ajar bersifat partisipatif & 3 & 3 & 3 & Valid \\
\hline 8. & Bahan ajar bersifat interaktif bagi siswa & 3 & 3 & 3 & Valid \\
\hline Rata & ata Aspek ke-II & 3 & & & Valid \\
\hline \multicolumn{6}{|c|}{ Kemampuan Berpikir Kreatif Matematis } \\
\hline 9. & $\begin{array}{l}\text { Prosedur kerja menunjang pencapaian } \\
\text { kemampuan berpikir kreatif }\end{array}$ & 3 & 3 & 3 & Valid \\
\hline 10. & $\begin{array}{l}\text { Latihan soal menunjang pencapaian } \\
\text { kemampuan berpikir kreatif }\end{array}$ & 4 & 4 & 4 & Sangat Valid \\
\hline Rata & ata Aspek ke-III & 3.5 & & & Sangat Valid \\
\hline \multicolumn{6}{|c|}{ Penampilan Fisik } \\
\hline 11. & Penampilan sampul bahan ajar menarik & 4 & 3 & 3.5 & Sangat Valid \\
\hline 12. & Bentuk dan ukuran huruf mudah dibaca & 4 & 4 & 4 & Sangat Valid \\
\hline 13. & $\begin{array}{l}\text { Bentuk dan ukuran huruf yang digunakan } \\
\text { konsisten }\end{array}$ & 4 & 3 & 3.5 & Sangat Valid \\
\hline Rata & ata Aspek ke-IV & 3.67 & & & Sangat Valid \\
\hline \multicolumn{6}{|c|}{ Kebahasaan } \\
\hline 14. & Struktur kalimat yang digunakan jelas & 3 & 3 & 3 & Valid \\
\hline 15. & Bahasa yang digunakan komunikatif & 3 & 3 & 3 & Valid \\
\hline 16. & Bahasa yang digunakan sesuai dengan EYD & 3 & 3 & 3 & Valid \\
\hline Rata & ata Aspek ke-V & 3 & & & Valid \\
\hline
\end{tabular}


Jurnal PAJAR (Pendidikan dan Pengajaran)

Volume 5 Nomor 2 Maret 2021 | ISSN Cetak : 2580 - 8435 | ISSN Online : 2614 - 1337

DOI : http://dx.doi.org/10.33578/pjr.v5i2.8221

\begin{tabular}{llllll}
\hline \multicolumn{2}{l}{ Tata Letak } & & & \\
\hline $17 . \quad$ Tata letak isi bahan ajar konsisten & 4 & 4 & 4 & Sangat Valid \\
$18 . \quad \quad$ Tata letak isi bahan ajar harmonis & 4 & 3 & 3.5 & Sangat Valid \\
19. $\quad$ Komposisi dan pemilihan warna menarik & 4 & 3 & 3.5 & Sangat Valid \\
\hline Rata-Rata Aspek ke-V & 3.67 & & & Sangat Valid \\
\hline
\end{tabular}

Berdasarkan tabel terlihat bahwa dari 19 butir pernyataan, 9 butir pernyataan berkategori valid, sedangkan 10 butir pernyataan berkategori sangat valid. Dilihat dari aspek untuk mengukur validitas modul, dari 5 aspek ada 2 aspek yang termasuk kategori valid, sedangkan 3 aspek lagi berkategori sangat valid. Secara keseluruhan berarti modul teknik integrasi sudah valid dan dapat digunakan kepada mahasiswa di matakuliah kalkulus integral.

Setelah modul dinyatakan valid, selanjutnya modul diberikan kepada mahasiswa beserta angket respon penggunaan modul. Skor jawaban mahasiswa pada angket tersebut digunakan untuk mengukur kepraktisan modul. Hasil respon mahasiswa tersebut dapat dilihat pada tabel berikut.

Tabel 5. Hasil Respon Mahasiswa Terhadap Penggunaan Modul

\begin{tabular}{|c|c|c|c|c|}
\hline No & Pernyataan & $\begin{array}{l}\text { Total Nilai } \\
\text { Kepraktisan }\end{array}$ & $\%$ NK & Kategori \\
\hline 1 & Modul yang digunakan menarik & 54 & 84.375 & $\begin{array}{l}\text { Sangat } \\
\text { Praktis }\end{array}$ \\
\hline 2 & $\begin{array}{l}\text { Modul yang digunakan dapat meningkatkan } \\
\text { semangat belajar }\end{array}$ & 49 & 76.5625 & Praktis \\
\hline 3 & $\begin{array}{l}\text { Bentuk dan ukuran huruf pada modul mudah } \\
\text { dibaca }\end{array}$ & 58 & 90.625 & $\begin{array}{l}\text { Sangat } \\
\text { Praktis }\end{array}$ \\
\hline 4 & $\begin{array}{l}\text { Materi yang disajikan pada modul mudah } \\
\text { dipahami }\end{array}$ & 52 & 81.25 & $\begin{array}{l}\text { Sangat } \\
\text { Praktis }\end{array}$ \\
\hline 5 & $\begin{array}{l}\text { Modul membantu Saya untuk menguasai materi } \\
\text { teknik integrasi }\end{array}$ & 54 & 84.375 & $\begin{array}{l}\text { Sangat } \\
\text { Praktis }\end{array}$ \\
\hline 6 & $\begin{array}{l}\text { Soal-soal dalam modul menantang untuk } \\
\text { dikerjakan }\end{array}$ & 43 & 67.1875 & Praktis \\
\hline 7 & $\begin{array}{l}\text { Modul membantu Saya untuk meningkatkan } \\
\text { kemampuan berpikir kreatif matematis }\end{array}$ & 43 & 67.1875 & Praktis \\
\hline 8 & $\begin{array}{l}\text { Saya tidak merasa terbebani dalam menggunakan } \\
\text { modul ini }\end{array}$ & 49 & 76.5625 & Praktis \\
\hline 9 & $\begin{array}{l}\text { Penggunaan modul ini menambah pengalaman } \\
\text { belajar Saya }\end{array}$ & 40 & 62.5 & Praktis \\
\hline 10 & $\begin{array}{l}\text { Bahasa yang digunakan dalam modul jelas, runtut, } \\
\text { dan mudah dipahami }\end{array}$ & 56 & 87.5 & $\begin{array}{l}\text { Sangat } \\
\text { Praktis }\end{array}$ \\
\hline Rate & Rata & 49.8 & 77.8125 & Praktis \\
\hline
\end{tabular}

Berdasarkan skor angket respon mahasiswa terhadap penggunaan modul teknik integrasi, terlihat bahwa dari 10 butir penilaian kepraktisan, 6 butir termasuk kategori praktis, sedangkan 4 butir lainnya termasuk kategori sangat praktis. Secara keseluruhan, penilaian kepraktisan modul berada pada nilai 49.8 dengan persentase sebesar $77.8125 \%$ dan termasuk kategori praktis. Oleh karena itu, dapat dikatakan modul yang dikembangkan sudah memenuhi kriteria kepraktisan.

Pengujian keefektifan modul dilihat dari peningkatan kemampuan berpikir kreatif matematis mahasiswa setelah diberikan modul teknik integrasi, dibandingkan dengan sebelum diberikan modul. Selanjutnya untuk melihat 
kategori peningkatan tersebut, besar $\mathrm{n}$-gain dibandingkan dengan kriteria n-gain yang telah ditentukan sebelumnya. Hasil perhitungan terkait skor kemampuan berpikir kreatif matematis mahasiswa dapat dilihat pada tabel berikut

Tabel 6. Perolehan Skor Kemampuan Berpikir Kreatif Matematis

\begin{tabular}{|c|c|c|c|c|c|}
\hline \multirow{2}{*}{$\begin{array}{c}\text { Kode } \\
\text { Mahasiswa }\end{array}$} & \multicolumn{4}{|c|}{ Skor } & \multirow{2}{*}{ Kategori } \\
\hline & Pretes & Postes & Gain & N-Gain & \\
\hline M1 & 4 & 9 & 5 & 0.625 & Sedang \\
\hline M2 & 0 & 8 & 8 & 0.67 & Sedang \\
\hline M3 & 5 & 12 & 7 & 1 & Tinggi \\
\hline M4 & 3 & 8 & 5 & 0.56 & Sedang \\
\hline M5 & 0 & 8 & 8 & 0.67 & Sedang \\
\hline M6 & 2 & 12 & 10 & 1 & Tinggi \\
\hline M7 & 1 & 6 & 5 & 0.45 & Sedang \\
\hline M8 & 3 & 8 & 5 & 0.56 & Sedang \\
\hline M9 & 3 & 8 & 5 & 0.56 & Sedang \\
\hline M10 & 5 & 12 & 7 & 1 & Tinggi \\
\hline M11 & 1 & 6 & 5 & 0.45 & Sedang \\
\hline M12 & 4 & 7 & 3 & 0.375 & Sedang \\
\hline M13 & 0 & 4 & 4 & 0.33 & Sedang \\
\hline M14 & 3 & 10 & 7 & 0.78 & Tinggi \\
\hline M15 & 3 & 7 & 4 & 0.44 & Sedang \\
\hline M16 & 5 & 10 & 5 & 0.71 & Tinggi \\
\hline Rata-Rata & 2.56 & 8.44 & 5.88 & 0.64 & Sedang \\
\hline
\end{tabular}

Berdasarkan tabel tersebut, terlihat bahwa, keenambelas mahasiswa sudah mengalami peningkatan kemampuan berpikir kreatif matematis. Kategori peningkatan kemampuan berpikir kreatif matematis mahasiswa-mahasiswa tersebut berada pada kategori sedang dan tinggi. Secara keseluruhan, rata-rata skor pretes 16 orang mahasiswa sebesar 2.56, sedangkan rata-rata skor postes sebesar 8.44. Berarti peningkatan rata-rata dari skor pretes ke postes adalah 5.88. Berdasarkan perhitungan n-gain, diperoleh n-gain sebesar 0.64 dengan kategori sedang. Artinya kemampuan berpikir kreatif mahasiswa dari sebelum diberikan modul dengan setelah diberikan modul mengalami peningkatan dengan kategori sedang.

Merujuk pada hasil penelitian ini, berarti modul teknik integrasi yang dikembangkan layak digunakan dan dapat meningkatkan kemampuan berpikir kreatif matematis mahasiswa. Hal ini sesuai dengan pernyataan Istikomah, dkk (2020), yaitu untuk mengembangkan kemampuan berpikir kreatif matematis dapat dilakukan dengan menggunakan bahan ajar yang disesuaikan dengan kebutuhan mahasiswa, salah satunya adalah modul.

\section{SIMPULAN DAN REKOMENDASI}

Penelitian pengembangan yang dilakukan ini menghasilkan produk bahan ajar berupa modul teknik integrasi pada matakuliah kalkulus integral. Pengembangan produk dilakukan dengan menggunakan model pengembangan ADDIE. Ditinjau dari hasil uji validitas modul yang dilakukan oleh 2 orang ahli, modul teknik integrasi telah dinyatakan valid dan layak digunakan mahasiswa pada matakuliah kalkulus integral. Berdasarkan hasil uji kepraktisan modul dengan menggunakan angket respon mahasiswa setelah menggunakan modul, secara umum modul teknik integrasi telah memenuhi kriteria kepraktisan. Hal ini dapat dilihat dari rata-rata persentase nilai kepraktisan sebesar 77.8125 dan berada pada kategori praktis. Merujuk pada hasil uji keefektifan modul, diperoleh hasil bahwa modul teknik integrasi sudah efektif untuk digunakan dan dapat meningkatkan kemampuan berpikir kreatif matematis. Ini terlihat dari rata- 
rata n-gain kemampuan berpikir kreatif matematis mahasiswa sebesar 0,64 dan berada pada kategori sedang. Karena modul teknik integrasi telah memenuhi kriteria validitas, kepraktisan, dan keefektifan, maka dapat dikatakan bahwa modul teknik integrasi yang dikembangkan dapat meningkatkan kemampuan berpikir kreatif matematis mahasiswa pada matakuliah kalkulus integral.

Merujuk pada hasil penelitian dan keterbatasan penelitian yang ada, peneliti memberikan rekomendasi bagi peneliti lain yang akan melakukan penelitian pada bidang yang sama. Pertama, uji coba lapangan yang dilakukan pada penelitian dapat dilakukan lebih dari satu kali dan dengan responden yang lebih banyak. Kedua, modul matakuliah kalkulus integral ini hanya membahas masalah teknik integrasi. Oleh karena itu, materi pada modul masih dapat diperluas, tidak terbatas pada teknik integrasi saja. Ketiga, modul matakuliah kalkulus integral tidak hanya bisa dikembangkan untuk meningkatkan kemampuan berpikir kreatif matematis. Modul ini masih dapat dikembangkan untuk meningkatkan kemampuan berpikir tingkat tinggi lainnya.

\section{DAFTAR PUSTAKA}

Akbar, S. (2013). Instrumen Perangkat Pembelajaran. Bandung: Remaja Rosdakarya

Amidi. (2018). Kemampuan Berpikir Kreatif Mahasiswa Semester 1 pada Mata Kuliah Matematika Dasar. Prisma, 1, 936 - 942

Arhasy, E. A.R, dan Mulyani, E. (2017). Kontribusi Model Problem Based Learning Berbantuan Media Software Maple Terhadap Kemampuan Berpikir Kreatif Matematis dan Self Regulated Learning Mahasiswa. Jurnal Siliwangi, 3(1), $\quad 197 \quad-\quad 203$. https://doi.org/10.37058/jspendidikan.v3i $\underline{1.190}$

Citroresmi, N., Sugiatno, Suratman, D. (2016). Pengembangan Modul Matematika Berbasis Masalah untuk Meningkatkan Kemampuan Penyelesaian Masalah dan Berpikir Kreatif Matematis Siswa. Jurnal
Pendidikan dan Pembelajaran
Khatulistiwa, 5(4)

Faelasofi, R. (2017). Identifikasi Kemampuan Berpikir Kreatif Matematika Pokok Bahasan Peluang. Jurnal Edumath, 3(2), 155 163.

https://doi.org/10.26638/je.460.2064

Hamdan. (2018). Industri 4.0: Pengaruh Revolusi Industri pada Kewirausahaan Demi Kemandirian Ekonomi. Jurnal Nusamba, 3(2), $\quad 1 \quad-8$. https://doi.org/10.29407/nusamba.v3i2.12 142

Handoko, H. (2017). Pembentukan Keterampilan Berpikir Kreatif pada Pembelajaran Matematika Model SAVI Berbasis Discovery Strategy Materi Dimensi Tiga Kelas X. EduMa, 6 (1), 85 - 95. 10.24235/eduma.v6i1.1711

Istikomah, Purwoko, R.Y., \& Nugraheni, P. (2020). Pengembangan E-Modul Matematika Berbasis Realistik Untuk Meningkatkan Kemampuan Berpikir Kreatif Siswa. Maju, 7(2), 63 - 71.

Lestari, I. (2013). Pengembangan Bahan Ajar Berbasis Kompetensi (Sesuai dengan Kurikulum Tingkat Satuan Pendidikan). Padang: Akademia Permata

Novalia, H., dan Noer, S. H. (2019). Pengembangan Modul Pembelajaran Matematika dengan Strategi PQ4R untuk Meningkatkan Kemampuan Berpikir Kreatif dan Kemandirian Belajar Siswa SMA. JPPM, 12(1), 51 - 65 . http://dx.doi.org/10.30870/jppm.v12i1.48 $\underline{54}$

Palah, S. (2017). Pengaruh Pendekatan OpenEnded Berstrategi M-RTE Terhadap Kemampuan Berpikir Kreatif Matematis Siswa pada Materi Persegipanjang. Mimbar Sekolah Dasar, 4(2), 139 - 149. https://doi.org/10.23819/mimbarsd.v4i2.7777

Pribadi, B. A. (2009). Model Desain Sistem Pembelajaran: Langkah Penting Merancang Kegiatan Pembelajaran yang Efektif. Jakarta: Dian Rakyat 
Ramdani, Y., Rohaeni, O., dan Sumardi, S. (2018). Pengembangan Instrumen dan Bahan Ajar Kalkulus Integral Melalui Strategi Scientific Debate. Ethos (Jurnal Penelitian dan Pengabdian Masyarakat, 6(1), $\quad 1 \quad-10$. https://doi.org/10.29313/ethos.v6i1.3231

Siswono, T. Y. E \& Budayasa, I. K. (2006). Implementasi Teori tentang Tingkat Berpikir Kreatif dalam Matematika. Prosiding Seminar Konferensi Nasional Matematika XIII dan Konggres Himpunan Matematika Indonesia di Jurusan Matematika FMIPA Universitas Negeri Semarang 24 - 27 Juli 2006, 1 - 16

Subekti, F. E., \& Akhsani, L. (2020). Pengembangan Modul Statistika Deskriptif Berbasis Pemecahan Masalah. Aksioma: Jurnal Program Studi Pendidikan Matematika, 9(3), 530 - 539. http://dx.doi.org/10.24127/ajpm.v9i3.286 $\underline{9}$

Sugiyono. (2012). Metode penelitian pendidikan (pendekatan kuantitatif, kualitatif, dan $R \& D)$. Bandung: Alfabeta

Suripah, S., dan Sthephani, A. (2017). Kemampuan Berpikir Kreatif Matematis Mahasiswa dalam Menyelesaikan Akar Pangkat Persamaan Kompleks Berdasarkan Tingkat Kemampuan Akademik. Pythagoras: Jurnal Pendidikan Matematika, 12(2), 149 - 160. https://doi.org/10.21831/pg.v12i2.16509

Swestyani, S., Masyuri, M., \& Prayitno, B.A. (2014). Pengembangan Modul IPA Berbasis Creative Problem Solving (CPS) untuk Meningkatkan Kemampuan Berpikir Kreatif Siswa pada Materi Pemanasan Global. Jurnal Pembelajaran Biologi, 6(2), 36 - 41 . 